\title{
家鬼膀脱に㧍けるVX2癌増殖過程の水プロトン核磁気共鳴 緩和時間に関する実験的研究
}

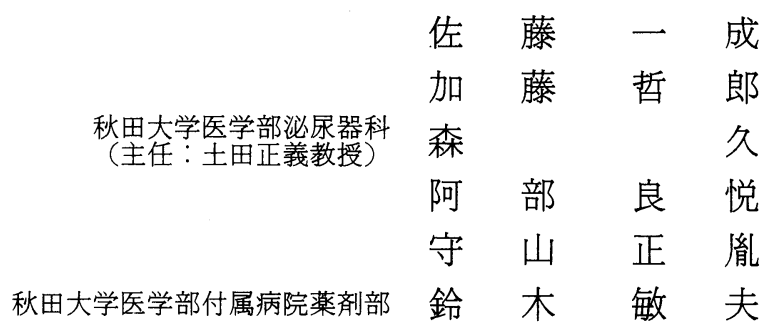

\section{${ }^{1} \mathrm{H}$ NUCLEAR MAGNETIC RESONANCE RELAXATION TIMES THROUGH VX CARCINOMA GROWTH IN RABBIT BLADDER}

\author{
Kazunari Sato, Tetsuro Kato, Hisashi Mori, Ryoetsu Abe and Masatsugu Moriyama \\ Department of Urology, Akita University, School of Medicine Akita, Japan \\ (Director: Prof. Seigi Tsuchida) \\ Toshio Suzuki \\ Department of Pharmacy, Akita University Hospital, Akita, Japan
}

Growth of VX2 carcinoma transplanted in the rabbit bladder was monitored by measuring nuclear magnetic resonance (NMR) relaxation times in the tumor, non-tumorous tissue of the tumor-bearing animals and serum. Rabbits injected with saline into the bladder wall were used as the control animals. The sampled materials were kept frozen with dry-ice until NMR analysis. Spin-lattice relaxation time (T1) and spin-spin relaxition time (T2) were measured with FT-NMR spectrometer at 2.1 tesla and $27^{\circ} \mathrm{C}$ within 24 hours after sampling.

$\mathrm{T} 1$ values of tumor tissue gradually increased along with tumor growth, being greater than the control values which remained constant. $\mathrm{T} 1$ values of the non-tumorous bladder tissue were lower than those of the tumor throughout the middle stage of tumor growth (4 week), and then showed prominent increase at the end stage of tumor growth (5-6 weeks). Advanced tumor growth may have caused water retention in the surrouding non-tumorous tissue.

$\mathrm{T} 2$ values of the tumor tissue did not show any characteristic changes as compared with the controls throuhout the progress of the tumor. T2 values of the non-tumorous bladder tissue also presented no peculiar change until the middle stage, but again showed a rapid increase as observed in $\mathrm{T} 1$ monitoring, in the end stage.

$\mathrm{T} 1$ and $\mathrm{T} 2$ values in both the non-tumorous tissue and the control bladder tissue well correlated with the tissue water content throughout the tumor growth, while these on the tumor tissue represented no significant correlation with the water content as a whole. However, the relaxation times in the tumor tissue well correlated with water content in the individual tumor stage, suggesting that relaxation times in tumor is influenced not only by water content but also by water-macromolecular interaction.

$\mathrm{T} 1$ and $\mathrm{T} 2$ in the serum of both the tumor-bearing and control animals showed no characteristic changes with unstable fluctuation of the values, but these of the tumor-bearing rabbit increased rapidly in the end stage of the tumor. Changes of T1 and T2 well correlated with total serum protein, indicating that prolongation of serum $\mathrm{T} 1$ and $\mathrm{T} 2$ reflects the nutritional condition. 
要旨：家鬼膀胱にV2腫瘍を移植して, 腫瘍, 非腫瘍部膀胱組織ならびに血清を経時的に採取し, 腫瘍の 発育に伴 ${ }^{1} \mathrm{H}$ の核磁気共鳴（NMR）緩和時間の変化を検討した。緩和時間はパルス FT-NMR 分光計 を用いて，T1（縦緩和時間）は Inversion Recovery 法, T2（横緩和時間）は Curr-Purcell-MeiboomGill 法で測定した。腫瑒の成長, 動物の体重変化ならびに転移の発生状況から 1 週から 4 週までが早期か ら中期， 5 週と 6 週が末期とした。

腫瘍 $\mathrm{T} 1$ は病期とともに徐々に延長する傾向をみせた。これに対して非腫瘍部 T1は中期まで腫瘍の T1より短かったが，末期になるとむしろ腫瘍 $\mathrm{T} 1$ より著しく延長した。一方，腫瘍 T2は病期による変化 を示さなかったが，非腫瘍部 T2は $\mathrm{T} 1$ と同様に，末期には著明に延長した。非腫瘍部と対照群の緩和時 間の延長は組織の水分含量の増加と平行した変化をみせた。これに対して, 腫瘍の緩和時間と水分含量 の間には，腫瘍成長の全期間を一括してみると有意な相関はなかった．しかし，各病期ごとにみると T1 と水分含量とはよく相関した。これは腫瘍の緩和時間に影響する因子は水分含量だけでなく，水と高分 子の相互作用，すなわち水の構造化も少なからず関与していることを示唆している.

血清緩和時間は腫瘍末期に延長した。この变化は血清蛋白濃度の低下と一致して括り，血清緩和時間 の变化が腫瘍に特異的現象とは考号られなかった.

\section{緒言}

核磁気共鳴 (Nuclear Magnetic Resonance, NMR) 現象とは，ある原子核が磁場中で特定周波数の電磁波 エネルギーを共鳴吸収し，次にこれを電磁波として放 出する現象をいう。この現象を解析することによって 物質の物理化学的性質を知ることができる。るた NMR 現象は対象とする検体を非侵襲的に測定するの で，生体試料をより生理的な条件下で分析できるとい ら特徴をもっている。このようなことから近年 NMR 現象が医学領域にも応用されるようになり, 種々の病 態解析が試みられている。悪性腫瘍もその重要な対象 疾患である。

1971年 Damadian が癌の水プロトン $\left({ }^{1} \mathrm{H}\right)$ の NMR 緩和時間が正常組織に比して延長することを発見し， NMR による癌診断の可能性を報告した ${ }^{1)}$.これを契機 として, 腫瘍組織と正常組織の緩和時間に関寸る数多 くの研究がなされ, 両者の NMR 上の特徵が詳しく検 討されるようになってきた。すすなわち諸家の報告をま とめると対象臟器や測定法に違いはあるが，腫瘍の緩 和時間は正常組織に比べで1.1から 3.0 倍に延長すると される233. また細胞の增殖速度が大きいほど4), あるい は組織の分化度が低い汪ど緩和時間が延長することが 知られている516). さらに, 担癌動物の健常部組織の緩 和時間は非担癌動物の同一組織の緩和時間に比較して 延長し7), 同様の变化は血清でも認められるとい $5^{8) \sim 10)}$. これらは脱分化に伴って当該細胞の緩和時間 が延長するが, その変化は健常組織あるいは生体全体 にも及ぶことを示唆し, NMR による腫瘍の早期発見, ならびに組織診への応用が期待されている.
しかし，腫瘍の NMRによる解析にはまだ解決され ない多くの問題が残されている。 その例として病期と ともに癌の緩和時間がいかなる変化を示すか, 正常組 織の緩和時間が癌組織のそれより延長する例がある が，それはいかなる場合かなどである。また，最近急 速に発展しつつある NMR-CT は生体組織の緩和時間 の分布を画像上に表現できるため, 病变の形態的のみ ならず質的解析ができる可能性を有しているが，その 基礎的資料はいまだ充分とはいえない。

このような現状を考慮して，本研究では移植実験腫 瘍の成長に伴う腫瘍, 健常組織ならびに血清のプロト ン ${ }^{1} \mathrm{H}$-の NMR 緩和時間の変化を検討してみた.

\section{実験対象ならびに方法}

緩和現象について：陽子数と中性子数のいずれか一 方，あるいは両者が奇数であるような原子核は，磁場 中である特定周波数の電磁波を共鳴的に吸収する，次 に電磁波照射を中断するとこの原子核は受け取ったエ ネルギーを同一周波数の電磁波として放出しながら， 元の熱平衡状態に戻っていく.この過程は緩和現象 (Relaxation) と呼ばれ，2つの機構が介在している. ひとつは綎緩和あるいはスピン一格子緩和と呼ばれ， その時定数は $\mathrm{T}_{1}$ で表わされる。これは激しく擋乱され て平衡状態から逸脱した原子核が平衡状態にもどる過 程に相当する。他は横緩和あるいはスピンースピン緩 和と呼ばれ，その時定数は $\mathrm{T}_{2}$ で表わされる。これは電 磁波照射中止直後にそろっていた個々の原子核スピン の位相が無秩序にずれる過程に相当する。これらはい ずれも種々の要因で変化するが，水では分子運動が自 由な場合に延長する。 
1. 移植膀脱腫瘍の作製：日本白色家鬼（体重 $2.7 \sim 3.2 \mathrm{~kg}$, 雌）を使用し，移植膀胼腫瘍を作製した。 根本ら ${ }^{111}$ の方法に準じ，家鬼の下腿に継代した $\mathrm{VX}_{2}$ 腫 瘍を摘出し，眼科剪刀で細切して糊状にした。これを Hanks buffered saline（ハンクス液）で希釈してガー ゼで濾過し， $1.5 \times 10^{6} コ / \mathrm{ml}$ の細胞浮遊液を調整した。 この間, トリプシン処理ならびに抗生物質の添加は行 わなかった。

ペントバルビタール $(25 \mathrm{mg} / \mathrm{kg}$ 静注) 麻酔下で家鬼 下腹壁に正中切開を掞き, 膀胱前壁浆膜下の 2 力所に 前述の細胞浮遊液 $0.2 \mathrm{ml}$ を注入した。これを移植膀脱 腫瘍群とし，20頭の家鬼を使用した。いっぽら対照群 とした15頭の家鬼には，同様の手術操作で細胞浮遊液 のかわりにハンクス液 $0.2 \mathrm{ml}$ を膀胱前壁浆膜下に注入 した。両群ともに感染防止のため, チカルシリンナト リウ $450 \mathrm{mg} / \mathrm{kg}$ を手術終了時に筋注した. な招未処置 の家鬼 3 頭を実験開始時の対照例とした.

2. 試料の採取と処置: 腫瘍移植後 1 週, 2 週, 4 週, 5 週ならびに 6 週に，両実験群から無作為にそれぞれ 3 ないし 4 頭の家鬼を抽出し,ペントバルビタール250 $\mathrm{mg}$ を急速静注して剖検し, 腫瘍の増殖および転移を 観察した。腫瘍の計測は一対の膀胱腫瘍のらち大型の ものを対象とし, その長径, 短径と厚さの積で表示し た。膀胱腫瘍の一部と所属リンパ節，ならびに遠隔転 移が疑われた部位の組織はホルマリン固定し, 病理組 織学的検索に供した。

移植膀胱腫瘍群では膀胱腫瘍の大きさを計測したの ち, ただちに腫瘍 2 個と非腫瘍部膀胱後壁 2 カ所から 小切片を摘出し, 対照群では膀胱後壁 2 力所から検体 を摘出した。この際，試料に付着した尿や血液は生理 食塩水で洗涤のらえガーゼで完全に除去し, 膀胼周囲 の脂肪組織, 結合織ならびに腫瘍壊死部も鋭的に可能 なかぎり除去した。同時に下大静脈から静脈血 $10 \mathrm{ml}$ を 採取し，血清を遠心分離した。膀胼からの NMR 測定 用検体は湿重量を測定したのち，ただちに10Фの NMR 試料管に入れ, 血清は $0.2 \mathrm{ml}$ を $5 \Phi$ の NMR 試料 管に入れ，ドライアイスを充填した魔法ビンで涷結保 存した.

血清については市販の血清総蛋白濃度測定キット (A/G B-test Wako, 和光純薬工業株式会社, 大阪) を 用いて，Biuret 法で血清総蛋白濃度を測定した。また $\mathrm{NMR}$ 緩和時間測定後, 膀胱の検体は $60^{\circ} \mathrm{C} て ゙$ 重量が一 定になるまで乾燥し, 先に求めた湿重量との比から水 分含量 (W/W\%) を求めた。
3. 緩和時間の測定 : 凍結保存した検体は18時間か ら24時間後に室温で徐々に解凍し, ${ }^{1} \mathrm{H}$ の NMR 緩和 時間を測定した. NMR 緩和時間の測定はパルス・フー リ土変換 NMR 分光計 (FX-90Q, 日本電子株式会社 製, 東京)を用い, $27^{\circ} \mathrm{C}$, 共鳴周波数 $89.6 \mathrm{MHz}$ で行っ た. $\mathrm{T}_{1}$ (スピン一格子緩和時間)は Inversion Recovery 法 $\left(180^{\circ}-\tau-90^{\circ}\right.$ pulse sequence), $\mathrm{T}_{2}$ (スピンースピン 緩和時間) は CPMG (Curr-Purcell-Meiboom-Gill) 法 を用いた。

予備実験として $\mathrm{VX}_{2}$ 膀脱腫瘍と非腫瘍部膀脂の緩 和時間を, 組織摘出直後と 24 時間凍結解凍後の 2 回に わたって測定し，凍結保存が緩和時間に及ぼす影響を 検討した. 摘出直後に対して24時間凍結解凍後に, $\mathrm{T}_{1}$

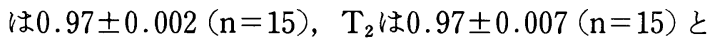
なり変化は極めて小さかった。

\section{結果}

腫瘍は指数関数的な増殖を示し，4 週以降になると 所属リンパ節，さらには肺への転移が順次発生した。 これに伴って体重は 5 週後から明らかに減少しはじ め, 6 週目には悪液質に陥った。組織学的には移植後 1 週で, 膀脱粘膜下に限局する多数の腫瘍細胞集団を 認め, 2 週後には膀胖粘膜下に結節状腫瘤を形成し,

4 週以後になると膀朕粘膜面に潰瘍を形成するととも に, 中心壊死による陥凹とそれを囲む結節状隆起を認 めた。な怙腫瘍の組織像には, 成長過程において特記 するよらな変化はみられなかった。

非腫瘍部の膀胼は 4 週まで組織学的にも特記すべき 変化を示さなかったが, 5 週以後になると間質の浮腫 が著明となった。対照群の膀胱組織には全期間を通じ て病的変化をみなかった。

1. 組織 $\mathrm{T}_{1}$ の経時的変化：Fig. 1に腫瘍, 非腫瘍部 膀胼ならびに対照群膀胱の $\mathrm{T}_{1}$ の経時的変化を示した。 対照群膀胀の $\mathrm{T}_{1}$ は実験開始時に $1.37 \pm 0.01 \mathrm{sec}$ (Mean \pm S.E)であったが, 経時的な変化はほとんどな く, 全観察期間を通じて腫瘍ならびに非腫瘍部膀胱の $\mathrm{T}_{1}$ より短かった。腫瘍部 $\mathrm{T}_{1}$ は移植後 1 週目に $1.43 \pm$ $0.03 \mathrm{sec}$ であったが, 徐々に延長して 6 週目には $1.52 \pm 0.03 \mathrm{sec}$ となった。 しかし 1 週と 6 週の $\mathrm{T}_{1}$ を比 較すると統計学的に有意な延長とはい充なかった。非 腫瘍部膀胀の $\mathrm{T}_{1}$ は 4 週までは腫瘍より短いが, それ以 後は著明に延長し， 5 週目 $(1.54 \pm 0.03 \mathrm{sec})$ と 6 週目 $(1.72 \pm 0.02 \mathrm{sec})$ は腫瘍部 $\mathrm{T}_{1}$ より長くなった。

つぎに各群の組織の水分含量の変化と $\mathrm{T}_{1}$ を比較し てみた。腫崵では 1 週から 6 週にかけて $\mathrm{T}_{1}$ 值は徐々に 
Fig. 1 T1 in VX2 bladder tumor (- -), nontumorous tissue in the tumor-bearing bladder $\left(-\boldsymbol{A}^{-}\right)$, and normal bladder with saline injection $(-\bigcirc-)$. Significant differences between tumor and others were marked as ${ }^{*}(p<0.05),{ }^{* *}(p<0.01)$ and $^{* * *}(\mathrm{p}<0.001)$.

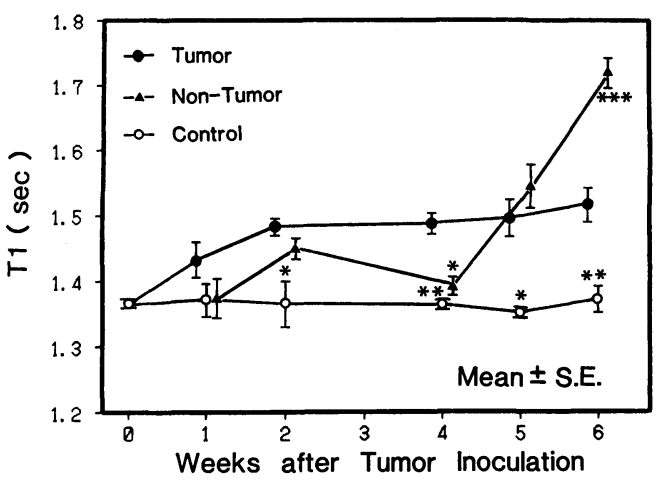

延長するのに対し，水分含量は逆に 1 週 $84.7 \pm 0.5 \%$

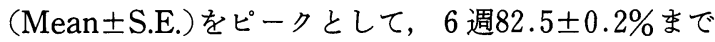
次第に減少した (Fig. 2)。これに対して非腫場部膀脱 と対照群膀胱においては，それぞれ $T_{1}$ 值と水分含量は ほ注平行した変動をみせた（Fig. 3,4)，とくに非腫瘍 部膀胱組織では 5 週と 6 週の $\mathrm{T}_{1}$ の延長が著しかった が，このとき水分含量も 4 週 $82.4 \pm 0.6 \%$ から 6 週 $86.8 \pm 0.1 \%$ まで大きく増加した。

2. 組織 $\mathrm{T}_{2}$ の経時的変化：Fig. 5 は腫瘍, 非腫瘍部 膀胱,ならびに対照群膀胱の $\mathrm{T}_{2}$ の経時的变化を示した ものである. 実験開始時の膀胱組織の $\mathrm{T}_{2}$ は $91.5 \pm 5.4$ msec (Mean士S.E) であり，その後 1 週から 4 週まで は腫瘍ならびに非腫瘍部に比して対照群膀胱の $\mathrm{T}_{2}$ が やや短いものの, 各群の $\mathrm{T}_{2}$ に大さな差はみられなかっ た. しかし 4 週以後になると非腫瘍部膀胼の $\mathrm{T}_{2}$ が明ら

Fig. $2 \mathrm{~T} 1\left(-\mathbf{O}^{-}\right)$and water content(-O-) in VX2 rabbit bladder tumor.

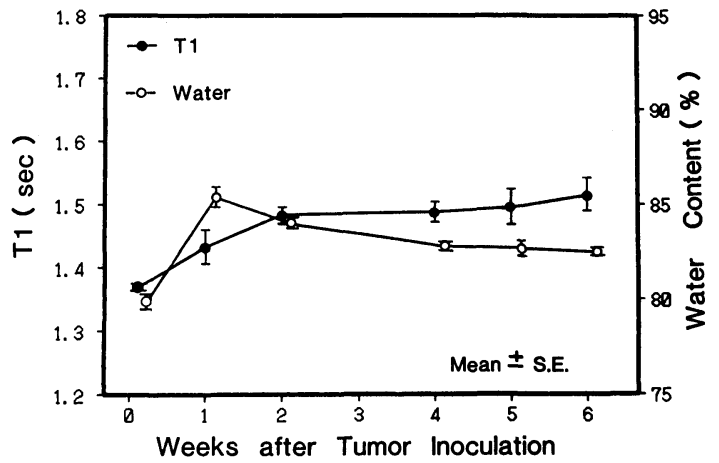

Fig. $3 \mathrm{~T} 1\left(-\mathrm{O}^{-}\right)$and water content $\left(-\mathrm{O}^{-}\right)$in nontumorous tissue of the tumorbearing rabbit bladder.

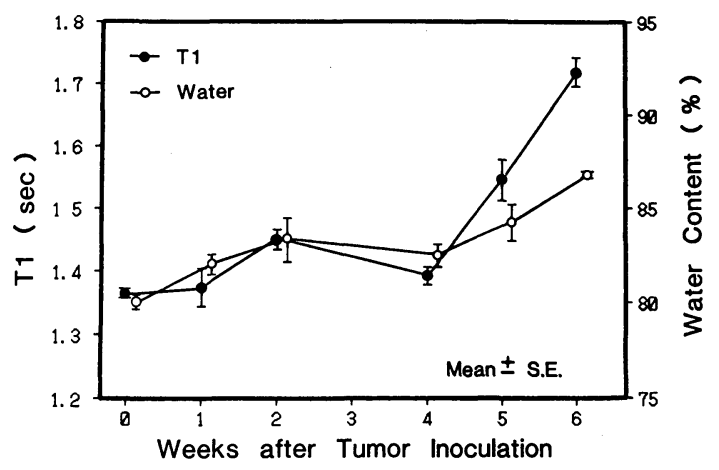

Fig. $4 \mathrm{~T} 1\left(^{-} \mathbf{-}^{-}\right)$and water content $\left(-\mathrm{O}^{-}\right)$in normal rabbit bladder tissue with saline injection.

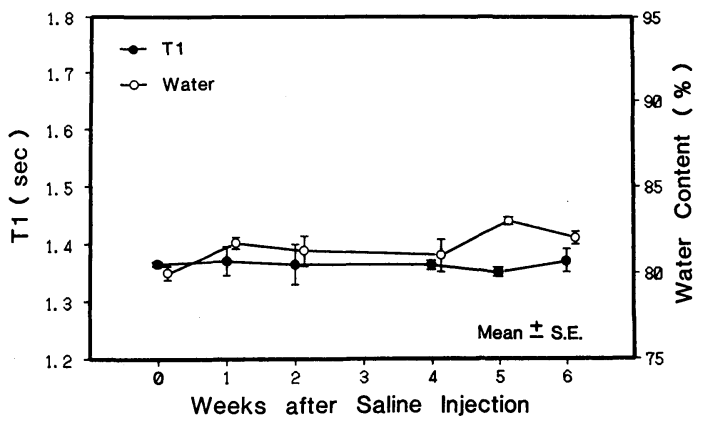

Fig. 5 T2 in VX2 bladder tumor(-)-), nontumorous tissue in the tumor-bearing bladder $-\boldsymbol{A}$ $-)$, and normal bladder with saline injection $(-\bigcirc$ $-)$. Significant differences between tumor and others were marked as ${ }^{* *}(\mathrm{p}<0.01)$ and ${ }^{* * *}(\mathrm{p}<$ 0.001 ).

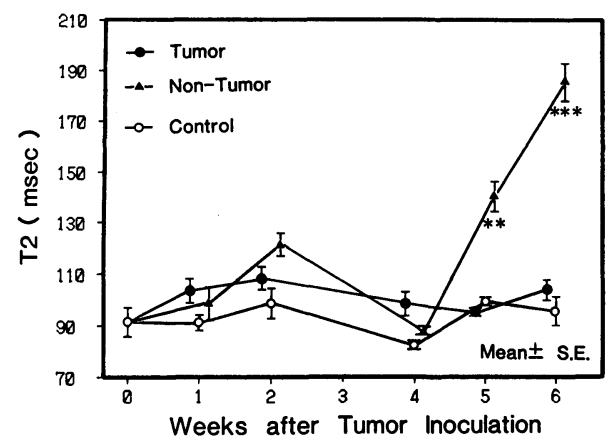

かに延長し， 5 週140.3土5.8msec， 6 週 $185.2 \pm 7.4$ msec となって，他の 2 群に比較して著しく増大した。 3. 組織の緩和時間 $\left(T_{1}, T_{2}\right)$ と水分含量 : Fig. 6は 
Fig. 6 Relationship between $\mathrm{T} 1$ and water content in non-tumorous bladder tissue of the VX2 tumor-bearing rabbit $(\boldsymbol{\Delta},-)$ and normal rabbit bladder tissue $(O, \cdots \cdots)$ with saline injection. Significant correlations were observed in both groups $(p<0.001)$. Correlation coefficient of the former was $r=0.87$ and that of the latter was $r=$ 0.71 .

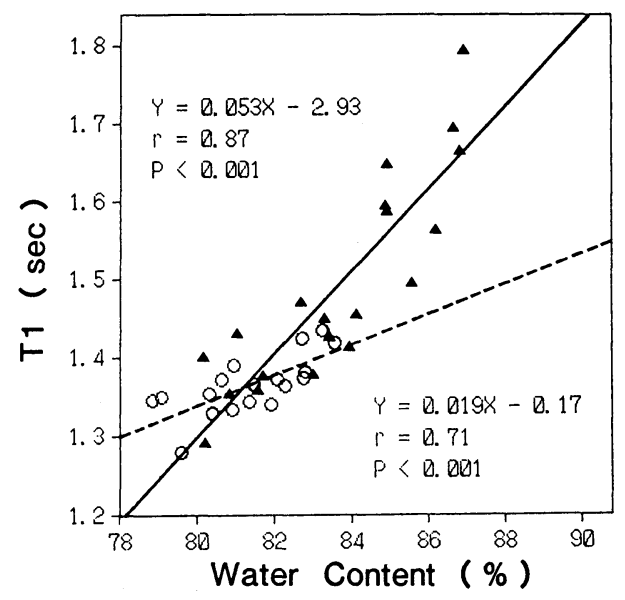

非腫瘍部膀胼と対照群膀胱における， $\mathrm{T}_{1}$ と水分含量の

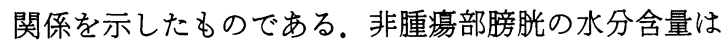
対照群膀胱に比べて広い分布をとった．しかし両者と もに水分含量が多いものほど $T_{1}$ 値も延長して扣り, 相 関係数はそれぞれ非腫瘍部膀胱では $\mathrm{r}=0.87 （ \mathrm{p}<$

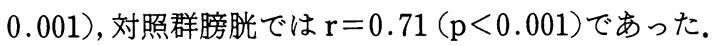

Fig. 7 Relationship between $\mathrm{T} 1$ and water content in bladder tumor at $1(\bigcirc), 2(\bigcirc), 4(\square), 5(\square)$ and $6(\square)$ weeks after VX2 tumor inoculation. Significant correlations $(\mathrm{p}<0.05)$ were observed at the 2nd, 4 th and 5 th week, respectively.

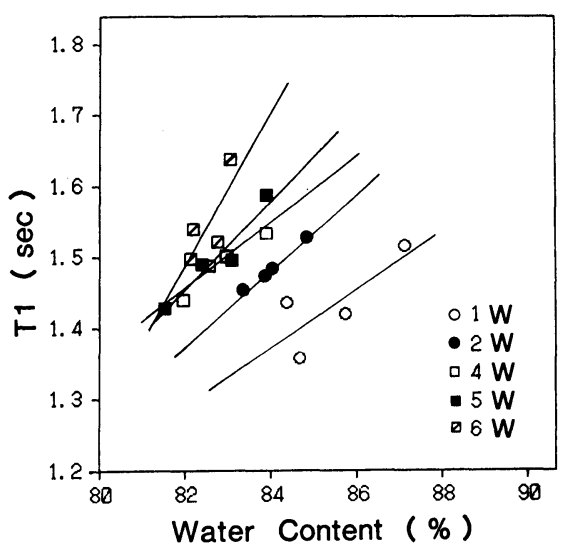

これに対して腫瘍では観測期間全体の測定値を一括し てみると， $T_{1}$ と水分含量には有意な相関がみられな かった $(\mathrm{r}=0.06)$. そこで各観測病期別に $\mathrm{T}_{1}$ と水分含 量を分析してみた（Fig. 7).その結果，いずれの病期 に扣いても水分含量の増加とともに $\mathrm{T}_{1}$ が延長し, とく に 2 週, 4 週, ならびに 5 週では $\mathrm{T}_{1}$ と水分含量との間 に統計学的に有意な相関を認めた $(\mathrm{p}<0.05)$. また

Fig. 8 Relationship between T2 and water content in non-tumorous bladder tissue of the VX2 tumor-bearing rabbit $(\boldsymbol{\Lambda},-)$ and normal rabbit bladder tissue with saline injection $(O, \cdots \cdots)$. Significant correlations were observed in both groups $(\mathrm{p}<0.001)$. Correlation coefficient of the former was $r=0.86$ and that of the latter was $r=$ 0.82 .

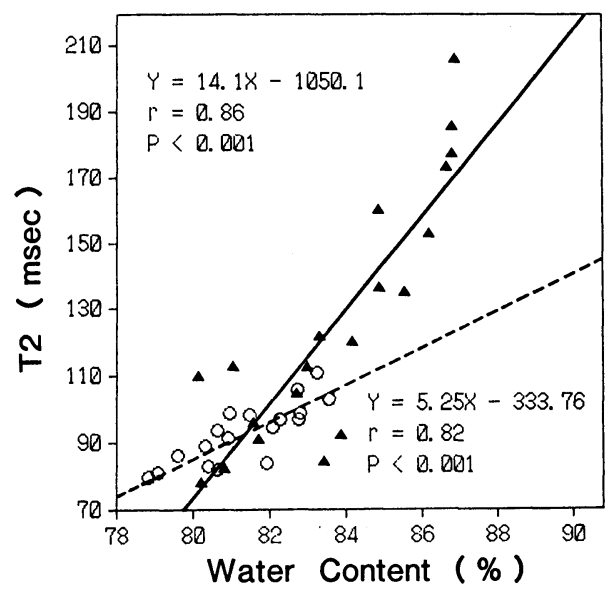

Fig. 9 Relationship between T2 and water content in bladder tumor at $1(\bigcirc), 2(\bigcirc), 4(\square), 5(\square)$ and $6(\square)$ weeks after VX2 tumor inoculation. Significant correlation $(\mathrm{p}<0.05)$ were observed at the 2 nd, 4 th and 6 th week, respectively.

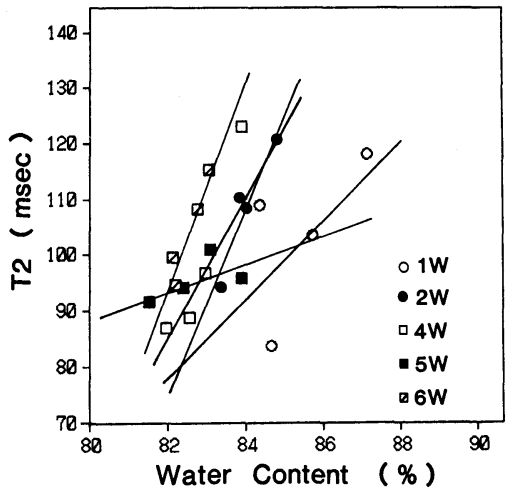


各々の回帰直線は観察された水分含量の範囲内では, 病期があとのものほど四の左方に位置する傾向がみら れた。

非腫瘍部膀胱ならびに対照群膀胱の $\mathrm{T}_{2}$ は $\mathrm{T}_{1}$ と同様 に, 水分含量の増加とともに延長し，それぞれの相関 係数は $\mathrm{r}=0.86(\mathrm{p}<0.001), \mathrm{r}=0.82(\mathrm{p}<0.001)$ で あった (Fig. 8)。一方腫瘍では前二者のよらな関係は 明らかではなかったので $(\mathrm{r}=0.48, \mathrm{p}<0.05)$, さらに 各病期別に $\mathrm{T}_{2}$ と水分含量の相関を調べた (Fig. 9). そ の結果いずれの病期でも, 水分含量の増加とともに $\mathrm{T}_{2}$ の延長がみられたが，とくに 2 週，4 週ならびに 6 週 では有意な相関が認められた $(\mathrm{p}<0.05)$ 。 また得られ た回帰直線は, 病期があとのもの活ど左方に位置する 傾向があったが, T、についてみられたほど明らかでは なかった。

4. 血清の $T_{1}$ と $T_{2}$ の経時的変化: 移植膀胖腫瘍群 と対照群の血清の $\mathrm{T}_{1}$ と $\mathrm{T}_{2}$ の経時的变化を，それぞれ

Fig. 10 T1 in rabbit serum with(-)- or without(-O-) VX2 bladder tumor. Significant diffrence was marked as * $(p<0.05)$.

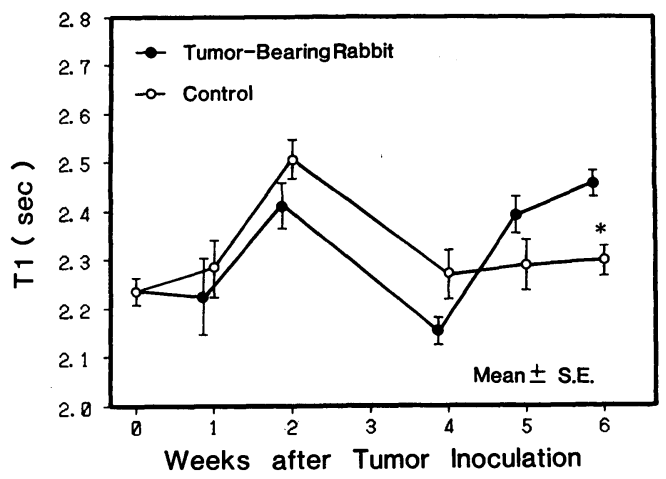

Fig. 11 T2 in rabbit serum with(-)-) or without $\left.(-)^{-}\right)$VX2 bladder tumor.

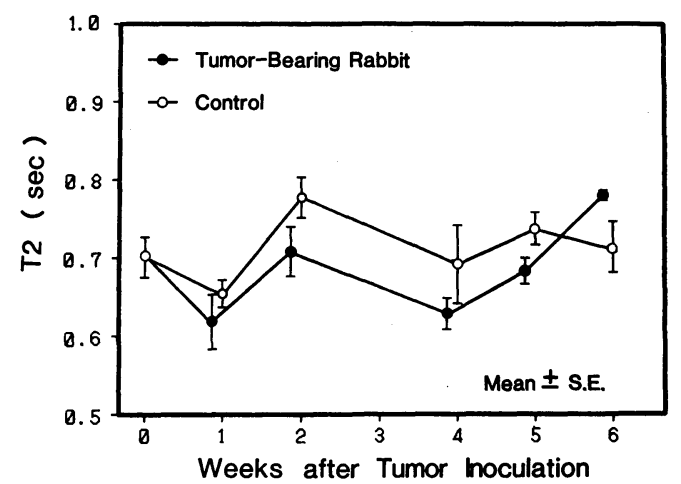

Fig. 10ならびに Fig. 11に示した. 全期間を一括する と移植膀胱腫瘍群の血清 $\mathrm{T}_{1}$ は2.30土0.16 sec (Mean \pm S.D.), 血清 $\mathrm{T}_{2}$ は0.68 $\pm 0.07 \mathrm{sec}$ (Mean $\pm \mathrm{S}$. D.) であり, 対照群の血清 $\mathrm{T}_{1}(2.32 \pm 0.11 \mathrm{sec})$ と $\mathrm{T}_{2}$ $(0.72 \pm 0.06 \mathrm{sec})$ との間に差はみられなかった。経時的 変化をみると 1 週から 4 週までは, $\mathrm{T}_{1}$ と $\mathrm{T}_{2}$ のいずれ も移植膀胼腫場群よりも対照群で延長していたが，両 群の差は統計学的に有意ではなかった。また，この時 期の緩和時間は両群ともほぼ同様な变動を示してい た.これに対して 4 週以後になると移植膀胼腫瘍群の 緩和時間が速やかに延長し， $T_{1}$ では 5 週以後，また $T_{2}$ では 6 週目に対照群の緩和時間よりも増大した。

5. 血清の緩和時間と血清総蛋白濃度 : 血清中の最 大成分である血清総蛋白と血清緩和時間との関係を検 討した。はじめに移植膀羘腫瘍群と対照群の血清総蛋 白濃度の变化をみた(Fig. 12). 両群の血清総蛋白濃度 は中期までほとんど差がなかったが，4 週以後には移 植腫腸群の血清総蛋白濃度が急速に減少する傾向を示 した。

つぎに血清総蛋白濃度と $\mathrm{T}_{1}$ とを比較した（Fig． 13). 両群の相関係数は移植腫瘍群では $\mathrm{r}=-0.56(\mathrm{p}<$ $0.05)$, 対照群では $\mathrm{r}=-0.60(\mathrm{p}<0.01)$ であり, 両群 の血清 $\mathrm{T}_{1}$ は血清総蛋白の増加に伴って短縮した。同様 に血清 $\mathrm{T}_{2}$ も血清総蛋白濃度の増加にともなって短縮 し (Fig. 14), その相関係数は移植腫瘍群では $\mathrm{r}=$ $0.67(\mathrm{p}<0.01)$, 対照群では $\mathrm{r}=-0.69(\mathrm{p}<0.01)$ で あった。

\section{考察}

生体高分子と水は相互作用のある協同系を形成して いるとされ，細胞内の水は生体高分子表面に結合して 運動が強く束縛された成分（結合水）とその周りを取

Fig. 12 Serum protein in rabbits with (-) without (-O-) VX2 bladder tumor.

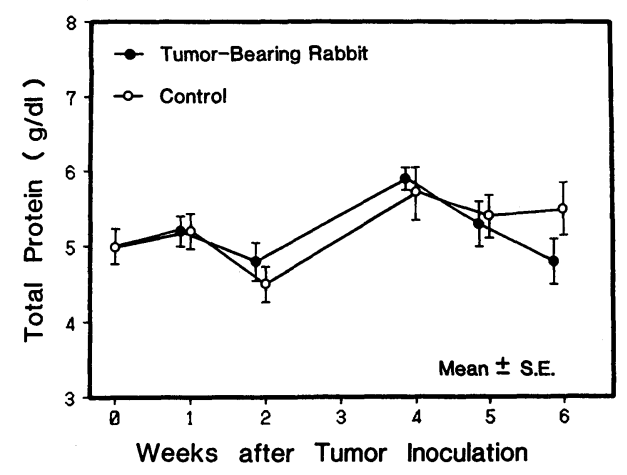


Fig. 13 Relationship between $\mathrm{T} 1$ and serum protein in tumor-bearing $\operatorname{rabbit}(\boldsymbol{\bullet},-)$ and rabbit with saline injection into the bladder $(O$, …..). Significant correlations were observed in both groups. Correlation coefficient of the former was $r=-0.56(p<0.05)$ and that of the latter was $\mathrm{r}=-0.60(\mathrm{p}<0.01)$.

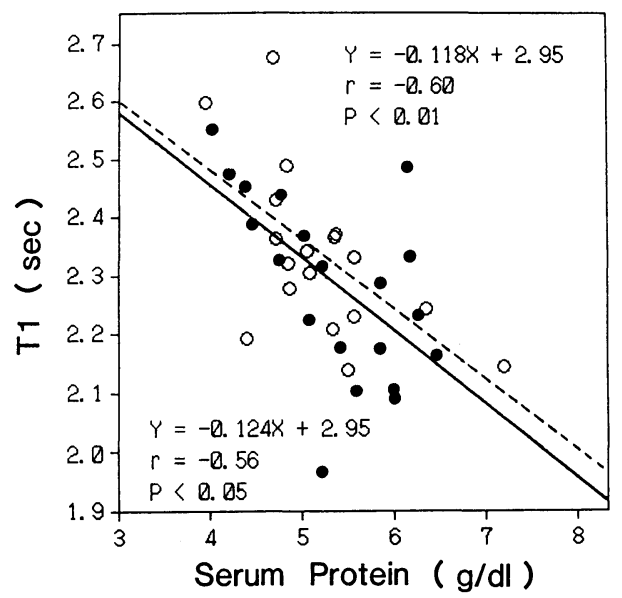

Fig. 14 Relationship between $\mathrm{T} 2$ and serum protein in tumor-bearing rabbit $(\boldsymbol{O},-)$ and rabbit with saline injection into the bladder $(O$, ......). Significant correlations were observed in both groups $(p<0.01)$. Correlation coefficient of the fomer was $\mathrm{r}=-0.67$ and that of the latter was $r=-0.69$.

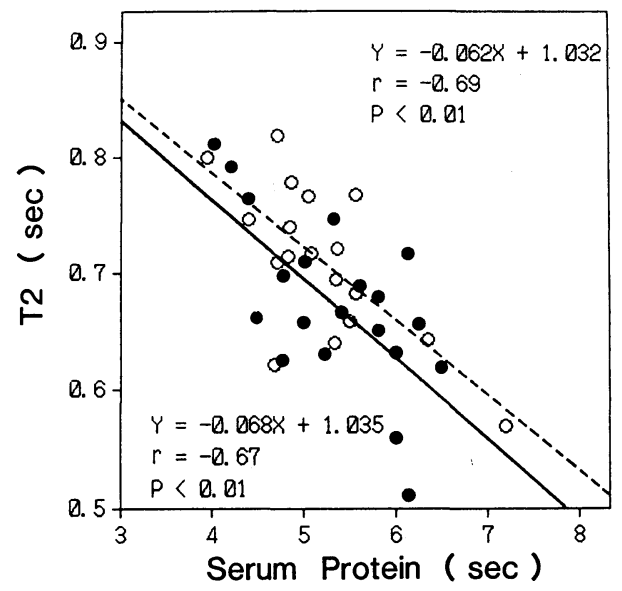

り巻く比較的自由度の高い成分（自由水）にわかれる と考えられている.水分子と結合する高分子としては, 蛋白質やグリコーゲン ${ }^{12)}$, ならびに核酸, 細胞膜, 細胞 微小管, 細胞微小繊維 ${ }^{13)}$ があげられている.さらに, 細
胞内の水の大部分は自由水とされるが，この自由水に しても純水よりは運動が束縛されて和り, 細胞内の水 はすべて大なり小なり構造化されているといら ${ }^{14)}$. 物 理化学的な作用により組織内高分子の構造が变化する そ, 水の構造化の程度に変化が生じ, 同時に自由水の 運動性も変化を受ける。緩和現象は原子核がエネル ギーを周囲へ放出して元の熱平衡状態へ戻る過程であ るから，それは水の運動性によって大きく影響を受け ることになる。例えば水分子の運動性が増加すると緩 和時間は延長する。

近年, 緒言に述べたように, 腫瘍組織では NMR 緩 和時間が延長するということが定説化されつつある. その理由として次の 2 つの可能性が提示されている. 第一に, 腫瘍組織内の含水量が一般に正常組織より増 加しているため, 自由水が増えて相対的に結合水が減 少するというもの．第二は腫瘍組織中では, 細胞内の 水の構造化の程度が正常組織にくらべて小さいため, 水の運動性が大きいとするものである. 前者は早くか

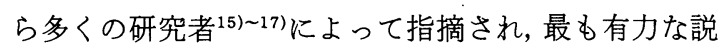
と考兄られてきた。しかし腫瘍の水分含量が正常組織 に比較して増加していない場合でも, 緩和時間の延長 することが指摘され ${ }^{6}$, 自由水の増量のみでは腫瘍の 緩和時間延長は説明されない。これに対して Beall ら は，培養腫瘍細胞の水分含量を变えずに染色体のみを 濃縮し, 有意に緩和時間が延長することを認めた ${ }^{13)}$.こ の所見については彼らは，染色体が濃縮するとその表 面積が減少し, 水分子の結合度が低下して運動性が高 まるため, 結果的に緩和時間が延長すると説明した。 さらに, Ling \& Tucker は正常細胞と癌細胞の $\mathrm{T}_{1}$ の 差について，両者の水分含量の違いによってもたらさ れる $\mathrm{T}_{1}$ の変化は平均 $10 \%$ 以下に過ぎず, 残りは他の原 因によって生ずることを指摘し，細胞内の水と高分子 の相互作用が緩和時間の変化に重要な役割をもつと強

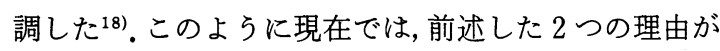
ともに腫瘍の緩和時間の延長に関与していると考兄ら れている.

しかし，腫瘍の緩和時間が常に非腫瘍組織に比べて 延長しているわけではなく, 逆に非腫瘍組織の緩和時 間が腫瘍より延長している場合があることも指摘され ている(4)59).このような現象を解析するには, 腫瘍の成 長に伴う緩和時間の変化を系統的に検討することが必 要である.Davis らはラットに腫瘍を移植し，8週まで 経時的に緩和時間を追跡したが有意な変化を認めな かった ${ }^{19)}$. Floyd らは腹水癌移植マウスの血清と肝の 
$\mathrm{T}_{1}$ を 5 日間追跡し, 血清では 1 日目々観察期間の後半 に対照マウスに比し16\%から18\%の延長を認めた。こ の時胆癌マウスと対照マウスの肝の $\mathrm{T}_{1}$ はいずれも漸 減したが, 胆癌マウスの肝の $\mathrm{T}_{1}$ が常に対照より延長し ていた ${ }^{8)}$.また, Kodama らはアゾ色素含有餌で飼育し たラットの肝，腎ならびに血清の緩和時間を追跡し，

標的臓器である肝の $\mathrm{T}_{1}$ が観察期間中に 2 つのピーク をとることを認めた。最初のピークは未成熟な肝細胞 過形成性結節の発生, 後半のピークは肝腫瘍の成長の 結果によるものと説明している。これに対して血清 $\mathrm{T}_{1}$ には有意な変化を認めなかったと述べた ${ }^{20)}$. さらに最 近では放射線治療による腫瘍の緩和時間の変化が検討 されるようになり，腫瘍縮小とともに腫瘍の緩和時間 が短縮すると報告されている ${ }^{2122)}$. しかしながら, 実験 モデルあるいは臨床例のいずれに打いても, 腫瘍の緩 和時間の自然経過に関する情報はまだ不十分である。

そこで本研究では $\mathrm{VX}_{2}$ 膀脱腫瘍の発育, 遠隔転移, ならびに宿主の全身状態を指標として，腫瘍成長と緩 和時間の経時変化を対比した. $\mathrm{VX}_{2}$ 腫瘍は根本らの報 告にあるように，移植細胞の数によって目的にあった 成長速度が得られ, 再現性のある均一な膀胱腫瑒モデ ルとすることができる ${ }^{11}$. 本研究に拈けるモデルでは, 腫崵の成長, 転移の発生ならびに宿主の体重変化から 1 週から 4 週を早期から中期, また 5 週と 6 週を末期 とすることができる。この実験モデルに怙いて早期か ら中期に限ってみれば, 既に諸家の報告にみられるよ うに, 腫瘍の緩和時間とくに $\mathrm{T}_{1}$ が非腫瘍部組織ならび に正常組織に比較して延長することが認められた。し かし末期になると非腫瘍部組織の緩和時間が著明に増 大し，腫瘍の緩和時間より明らかに延長した。これは 腫瘍と非腫瘍部組織の緩和時間の関係は一定ではな く, 腫瘍組織の成長に伴ってそれぞれ別々に変化し, しかも非腫湟部組織の緩和時間の変化が大きいため, 腫瘍組織緩和時間より延長する場合があることを示し ている。非腫瘍部組織に扮ける緩和時間と水分含量は 平行して变動しており, かつ腫瘍の成長につれて周囲 健常組織の浮腫が組織学的にも観察された。このこと から，末期に拈ける非腫瘍部組織の著明な水分含量の 増加が，同部の緩和時間の延長に大きく関与したもの と考えられる。

これに対して Fig. 2にみるように，腫場に拈ける緩 和時間と水分含量の相関は低く, とくに $\mathrm{T}_{1}$ にいては ゼロ相関に近かった。乙かし，腫瘍の緩和時間と水分 含量の関係を腫瘍成長の病期ごとに分けて検討する
と，各病期に扮いては水分含量の増加とともに，緩和 時間が延長する傾向がみられた。すすなわち， $\mathrm{T}_{1}$ では 2 週, 4 週，ならびに 5 週で， $\mathrm{T}_{2}$ では 2 週， 4 週，なら びに 6 週でそれぞれ統計学的に有意な正の相関を認め た。この時, 各回帰直線は病期とともに打㧤むね左方 に移動する傾向をみせた。この結果は, 腫崵の緩和時 間は同一病期についてみれば水分含量に相関するが， 一方では腫瘍は発育とともに以前とは異なる NMR 上の新たな性質を獲得するようになることを示唆して いる.

Ling \& Tuckerによると, ラット拈よびマウスの正 常の肝, 腎, 脾, 脳ならびに筋について, 各臟器に電 解質液を添加して 4 から 5 段階に水分含量を变化させ ると臟器ごとに緩和時間の変化の度合いが異なったた め, $\mathrm{T}_{1}$ と水分含量の関係を表す直線は臟器の数に別れ たと報告した ${ }^{18)}$.この結果は, 腫瘍の成長時期ごとに緩 和時間と水分含量の相関が異なるといら前述の自験成 績とよく似ている. Ling \& Tucker の結果は, 組織水 分含量に対応する緩和時間の变化が各臓器で特有のパ ターンをとり, それは各臓器の組織構築の基本をなす 高分子構築の差異によることを強く示唆している。本 研究の $\mathrm{VX}_{2}$ 膀胱腫崵では, その成長過程において光学 顕微鏡レベルでの組織構築の変化はみせなかったが, 水分含量とは無関係に緩和時間が次第に延長した。こ れらの知見を総括すると，腫湯の成長が進むにつれて 組織高分子の構築が水分子の運動性を高める方向に変 化し，その結果腫瘍の緩和時間が徐々に延長すると解 釈できよう。

Grösch \& Noack は蛋白（ウシアルブミン）溶液中 の ${ }^{1} \mathrm{H}$ は蛋白分子中, 蛋白分子に随伴した水ならびに蛋 白分子から離れた水のいずれかに属するといら 3 相モ デルを提唱した。そして，実際に観測される $\mathrm{T}_{1}$ 緩和率 ( $\mathrm{T}_{1}$ 緩和時間の逆数) は各相の成分比率ならびに $\mathrm{T}_{1}$ 緩 和に依存することを示した ${ }^{23)}$ ，さらに Koivula らは Grösch \& Noack の説をもとに, 蛋白溶液の $\mathrm{T}_{1}$ 緩和率 が蛋白濃度に相関することを理論的ならびに実験的に 証明した ${ }^{10)}$. 本研究でも担癌家鬼に抢ける血清緩和時 間がいずれも血清蛋白濃度の経時的変化とほぼ逆の変 動を示し，かつ血清緩和時間と血清蛋白濃度とは有意 な負の相関関係にあることが明らかに示された。血清 の成分は蛋白を除外すれば大部分が水なので，自験成 績は血清の $\mathrm{T}_{1}$ が水分含量に間接的に正の相関をする ことを意味している。

さて, 一般に担癌動物の血清蛋白濃度の変化は早期 
ではみられないことが多く，かつ癌の存在を直接示す ものではない。本研究でも早期から中期まで担癌家鬼 の全身状態は良好で，血清蛋白濃度は対照群と差がな く, 末期に至って血清蛋白濃度の低下と同様に緩和時 間間の延長をみた。血清の緩和時間に影響を与える因 子は, 単に血清の蛋白濃度だけでなく, 蛋白組成9なら びに電解質の濃度と組成 ${ }^{8}$ も考光られているが，少な くとも本研究の結果は血清の緩和時間の変化に対して 血清蛋白濃度が重要な因子であることを示している。 しかし血清蛋白濃度が低下するのは腫瘍の末期であ り, 発癌あるいは担癌状態を反映する指標とはならな いことは明らかである。

本研究は移植実験腫瘍の NMR 緩和時間を in vitro で解析したものであるが,一般に in vitro と in vivo の 緩和時間測定值はよく相関することが明らかにされて いる24)25). したがって自験成績は, NMR-CT上におけ る緩和時間から腫瘍を識別することが必ずしも容易で はないことを示唆するものと考学る。るた生体にあっ ては腫瘍の中心部変性壊死, 周囲組織の反応, 局所の 血流状態などが緩和時間に複雑に影響することが想定 され(6)27)，これら諸因子を含めた多角的な基礎研究が さらに必要になると思われる。

\section{総括}

家鬼移植膀胀腫湯の増殖過程における ${ }^{1} \mathrm{H}$ の NMR 緩和時間の変化を検討した。

1. 腫瘍の $\mathrm{T}_{1}$ は腫瘍の成長とともに徐々に延長する 傾向をみせた。非腫瘍部膀胼の $\mathrm{T}_{1}$ は中期までは腫瘍の $\mathrm{T}_{1}$ より短いが，末期になるとこの関係は逆転して腫瘍 の $\mathrm{T}_{1}$ より延長した。

2.これに対して腫瘍の $\mathrm{T}_{2}$ の病期に伴ら変化は認め られなかったが, 非腫瘍部膀胱の $\mathrm{T}_{2}$ は $\mathrm{T}_{1}$ と同様に末 期になると著明に延長した。な就対照群の緩和時間に

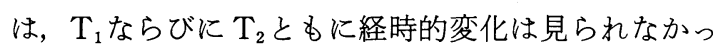
た。

3. 緩和時間の延長には水分含量の増加と水と高分 子の相互作用の変化との両者が関与するが, 腫瘍では 後者の影響をより強く受けることを示す成績が得られ た。

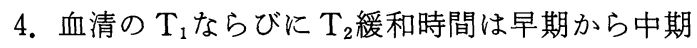
には移植膀羘腫瘍と対照群の間で差がなく, 担癌末期 になると初めて移植膀胱腫瘍群が対照群に比して延長 した. この血清緩和時間の延長は, 血清蛋白の低下と よく相関した。

5. 以上の所見は, NMR-CTによる腫瘍診断法を確
立する上で, 重要な参考資料になるものと思われる.

本研究の遂行にあたり技術上の指導を頂いた日本電子株 式会社医用技術科の江口恵二氏, 梅田雅宏氏に深く感謝し たす。

なお本研究は昭和59年度文部省科学研究費 (59480324) に より行った.

1) Damadian, R.: $\begin{aligned} & \text { 文 } \text { Tumor detection by nuclear } \\ & \text { The }\end{aligned}$ magentic resonance. Science, 171, 1151-1153, 1971.

2) de Certaines, J., Herry, J.Y., Lancien, G., Benoist, L., Bernard, A.M. and Le Clech, G.: Preliminary notes Evaluation off human thyroid tumors by porton nuclear magentic resonance. J. Nucl. Med., 23, 48-51, 1982.

3）清水哲也, 田中邦雄：NMR 断層画像の集検への 期待. 綜合臨床, 31，1797-1800， 1982.

4) Hollis, D.P., Saryan, L.A. and Morris, H.P.: A nuclear magnetic resonance study of water in two Morris hepatomas. Hopkins Med. J., 131, 441-444, 1972.

5) Schara, M., Sentjurc, M., Auersperg, M. and Golouh, R.: Characterization of malignant thyroid gland tissue by magentic resonance methods. Br. J. Cancer, 29, 483-486, 1974.

6) Beall, P.T., Asch, B.B., Chang, D.C., Medina, D. and Hazlewood, C.F.: Distinction of normal, preneoplastic, and neoplastic mouse mammary primary cell cultures by water nuclear magentic resonance relaxation times. J. Natl. Cancer Inst., 64, 335-338, 1980.

7) Hazlewood, C.F., Cleveland, G. and Medina, D. : Relationship between hydration and proton nuclear magentic resonance relaxation times in tissue of tumor-bearing and non-tumor-bearing mice: Implications for cancer detection. J. Natl. Cancer Inst., 52, 1849-1853, 1974.

8) Floyd, R.A., Leigh, J.S. Jr., Chance, B. and Miko, M.: Time course of tissue water proton spin-lattice relaxation in mice developing ascites tumors. Cancer Res., 34, 89-91, 1974.

9) de Certaines, J., Rivet, P., Bernard, A.M., Gailler, J., Benoist, L. and Morin, P.: Nucler magentic resonance study of cancer: Systemic effect on the proton relaxation time $\left(T_{1}\right.$ and $\left.T_{2}\right)$ of human serum. Cancer Detection and prevention, 4, 267-271, 1981.

10) Koivula, A., Suominen, K., Timonen, T. and Kiviniitty, K.: The spin-lattice relaxation time in the blood of healthy subjects and patients with malignant blood disease. Phys. 
Med. Biol., 27, 937-947, 1982.

11）根本良介, 森 久, 岩田克夫, 加藤哲郎, 阿部良 悦, 原田昌興：膀胼癌の局所治療汇関する実験的 研究1. 家鬼移植腫瘍 $\left(\mathrm{V}_{2}\right.$ carcinoma) 用いた膀 胱癌実験モデレルの確立。日泌尿会誌, 72, 1113-1119, 1981.

12) Block, R.E., Maxwell, G.P. and Branam, D.L.: Nuclear spin relaxation in solutions prepared from normal and tumor hepatic tissues: Brief communication. J. Natl. Cancer Inst., 59, 1731 $-1735,1977$.

13) Beall, P.T., Hazlewood, C.F. and Rao, P.N.: Nuclear magnetic resonance patterns of intracellular water as a function of Hela cell cycle. Science, 192, 904-907, 1976.

14）上平 恒：生体中の水. 蛋白質核酸酵素. 21 , 575-582, 1976.

15) Hollis, D.P., Saryan, L.A., Eggleton, J.C. and Morris, H.P.: Nuclear magentic resonance sttudies of cancer. VI. Relationship among spinlattice relaxation times, growth rate, and water content of Morris hepatomas. J. Natl. Cancer Inst., 54, 1469-1472, 1975.

16) Eggleton, J.C., Saryan, L.A. and Hollis, D.P.: Nuclear magentic resonance investigations of human neoplastic and abnormal nonneoplastic tissues. Cancer Res., 35, 1326-1332, 1975.

17) Inch, W.R., McCredie, J.A., Kinspel, R.R., Thompson, R.T. and Pinter, M.M.: Water content and proton spin relaxation for neoplastic and non-neoplastic tissues from mice and humans. J. Natl. Cancer Inst., 52, 353-356, 1974.

18) Ling, G.N. and Tucker, M.: Nuclear magnetic resonance relaxation and water contents in normal mouse and rat tissues and in cancer cells. J. Natl. Cancer Inst.. 64, 1199-1207, 1980.

19) Davis, P.L., Sheldon, P., Kaufman, L., Crooks, L., Margilis, A.R., Miller, T., Watts, J., Arak- awa, M. and Hoenninger, J.: Nuclear magnetic resonance imaging of mammary adenocarcinomas in the rat. Cancer, 51, 433 $-439,1983$.

20) Kodama, M., Ohki, T., Saittô, H., Nagata, C. and Tagashira, Y.: Biphasic change of proton magnetic relaxation times during azo-dye hepatocarcinogenesis. Br. J. Cancer, 37, 233 $-236,1978$.

21) Bakker, C.J.G. and Vriend, J.: Proton spinlattice relaxation studies of tissue response to radiotherapy in mice. Phys. Med. Biol., 28, 331 $-340,1983$.

22）田中邦雄，日下部光俊，菊池雄三，山田芳文，清水 哲也，阿部養右衛門：磁場焦点法 NMR に上る放 射線照射前後に扮ける緩和時間の無侵襲計測。 NMR 医学 (予稿集)，4，246-247，1984.

23) Gröoch, L. and Noack, F.: NMR relaxation investigation of water mobility in aqueous bovine serum albumin solutions. Biochem. Biophys. Acta, 453, 218-232, 1976.

24）堀川義治，成瀬昭二，田中忠蔵，平川公義，西川弘 恭，清水公治，喜利元貞： NMR-CT 像の基礎的 解釈一in vitro 緩和時間との対比一. NMR 医学, 4, 57-65, 1984

25) Ling, C.R. and Foster, M.A. : Changes in NMR relaxation time associated with local inflammatory response. Phys. Med. Biol., 27, 853-860, 1982.

26）山田 進，山浦玄嗣，山田健嗣，吉岡清郎，松沢大 樹：悪性腫演の診断と NMR. 医学のあゆみ, 127, 1392-1398, 1983

27) Moon, K.L. Jr., Davis, P.L., Kaufman, L., Crooks, L.E., Sheldon, P.E., Miller, T., Brito, A. C. and Watts, J.C.: Nuclear magnetic resonance imaging of a fibrosarcoma tumor implanted in the rat. Radiology, 148, 177-181, 1983.

（1984年12月 24 日受付） 